\title{
Pengaruh Ekstrak Air Rumput Teki (Cyperus rotundus) Terhadap Pertumbuhan dan Kandungan Klorofil Padi Gogo Varietas Inpago 8
}

\section{Effect of Aquaeous Extract Purple Nutsedge (Cyperus rotundus) on Growth and Content of Chlorophyll Upland Rice Variety Inpago 8}

\author{
Mia A. Agustin, Zulkiflii , Tundjung T. Handayani, dan Martha L. Lande \\ Jurusan Biologi FMIPA Universitas Lampung \\ Jalan Soemantri Brodjonegoro No.1. Bandar lampung, Indonesia, 35145 \\ *E-mail : zuls97287@ gmail.com
}

\begin{abstract}
The purpose of this research is to know whether the aqueous extract of purple nutsedge (Cyperus rotundus) have an effect on the growth and chlorophyll content of upland rice seedling of Inpago 8 varieties. This research was conducted at Botanical Laboratory of Biology Department Faculty of Mathematics and the Natural Sciences University of Lampung from September to October 2017. The experiments were carried out in a complete randomized design with the main factors being aqueous extract of purple nutsedge with 5 level: $0 \% v / v$ (control), 5\% v/v, 10\% v/v, 15\% v/v, and 20\%v/v. Parameters measured were shoot length, fresh weight, dry weight, relative water content, and total chlorophyll content of rice seedling. Homogeneity of variance was determined by the Levene test at 5\% significant level. Analysis of variance and Tukey HSD test is done at 5\% significant level. The results showed that the concentration of extract correlated quadratic with shoot length where the maximum shoot length was $3.9 \mathrm{~cm}$ at $10 \%$ extract concentration. Fresh weight and relative water content maximum were $73.21 \mathrm{mg}$ and $76 \%$ respectively at concentrations of $14 \%$ and $10 \%$. The minimum total chlorophyll content was $0.47 \mathrm{mg} / \mathrm{g}$ tissue at a concentration of $11 \%$. There was no significant effect on the dry weight of the seedling. From the results of the study, it was concluded that the extract of purple nutsedge at a concentration below 14\% was a growth stimulator, but it was an inhibitor of chlorophyll biosynthesis.Keyword: Chlorophyll, Growth, Upland rice variety Inpago 8, Purple nutsedge
\end{abstract}

Keywords: Chlorophyll, Inpago 8, Purple Nutsedge

Disubmit : 04 Juli 2018; Diterima: 02 Agustus 2018, Disetujui :07 September 2018

\section{PENDAHULUAN}

Tanaman padi (Oryza sativa L.) merupakan tanaman pangan yang sangat penting bagi keberlangsungan hidup manusia di muka bumi. Kebutuhan beras yang semakin meningkat karena jumlah penduduk yang setiap tahunnya meningkat sekitar $2 \%$ per tahun membuat konsumsi beras meningkat (Pertanian, 2010).

Padi dibedakan dalam dua tipe yaitu padi kering (padi gogo) yang ditanam di dataran tinggi dan padi sawah yang ditanam di dataran rendah yang memerlukan penggenangan air (Aak, 1995). Salah satu masalah yang dihadapi padi gogo adalah gulma yang menghasilkan senyawa alelopati yang dapat mempengaruhi pertumbuhan dan perkembangan padi gogo. Gulma rumput teki (Cyperus rotundus) mengandung senyawa 
alelopati yang dapat menghambat pertumbuhan dari tanaman padi. Kandungan dari tajuk rumput teki adalah asam fenolat sedangkan umbi rumput teki mengandung hidroksibenzoat, caffeat, ferulat, vanilat dan klorogenat (El-Rokiek et al., 2010).

Hasil penelitian sebelumnya yang dilakukan oleh (Nadu, 2014) tentang ekstrak air tanaman $C$. rotundus terhadap pertumbuhan padi dengan menggunakan berbagai konsentrasi pada perkecambahan benih dan bibit pertumbuhan beberapa padi ( O. sativa L.) kultivar yaitu ADT-36, BPT-5204 dan IR-20 yang dihasilkan bahwa rumput ini sebagai penghambatan persentase perkecambahan, panjang kecambah, jumlah, berat badan dan klorofil isi kering bibit berusia 15 hari dari ketiga kultivar beras dan efek penghambatan ekstrak adalah konsentrasi tergantung.

Dalam makalah ini peneliti melaporkan pengaruh ekstrak air rumput teki terhadap pertumbuhan dan kandungan klorofil kecambah padi gogo varietas Inpago 8 terhadap panjang tunas, berat segar, berat kering, kadar air relatif, dan klorofil total kecambah padi gogo varietas Inpago 8.

\section{METODE PENELITIAN}

Penelitian ini telah dilakasanakan di Laborarotium Botani Jurusan Biologi Fakultas Matematika dan Ilmu Pengetahuan Alam Universitas Lampung dari bulan September sampai Oktober 2017.

Penelitian dilaksanakan dalam Rancangan Acak Lengkap (RAL) dengan ekstrak air rumput teki sebagai faktor utama yang terdiri dari 5 taraf konsentrasi : sebagai kontrol 0\% v/v, 5\% v/v, 10\% v/v, 15\% $\mathrm{v} / \mathrm{v}$, dan $20 \% \mathrm{v} / \mathrm{v}$ dengan masing-masing 5 ulangan. Parameter dalam penelitian ini adalah nilai tengah panjang tunas, berat segar, berat kering, kadar air relatif, dan klorofil total kecambah padi gogo varietas Inpago 8.

10 gram bubuk kering rumput teki dilarutkan dalam $200 \mathrm{ml}$ aquades dan dibiarkan selama 48 jam pada suhu ruang dengan sekali-kali di aduk. Selanjutnya larutan disaring kedalam beaker glass dengan kertas Whatman no.1 sehingga diperoleh larutan stok dengan konsentrasi $5 \% \mathrm{~b} / \mathrm{v}$. Larutan stok diencerkan dengan aquades sehingga diproleh larutan dengan konsentrasi 5\% v/v, 10\% v/v, 15\% v/v, dan 20\% v/v.

Seleksi benih padi dengan cara merendam benih dalam aquades selama 10 menit. Benih yang tenggelam diambil untuk selanjutnya dikecambahkan sedangkan benih yang mengapung dan sampah dibuang. Benih yang telah diseleksi diambil untuk dikecambahkan. Selanjutnya, benih direndam dalam 5 konsentrasi ekstrak air rumput teki yaitu $0 \% \mathrm{v} / \mathrm{v}$ (kontrol), 5\% v/v, 10\% v/v, 15\% v/v, dan 20\% v/v selama 24 jam. Kemudian benih padi yang telah direndam ekstrak rumput teki selama 24 jam dikecambahkan dalam 5 nampan plastik yang telah dilapisi dengan tisue dan dibasahi dengan aquades. Jumlah benih yang digunakan sebanyak 500 butir benih padi gogo varietas Inpago 8, dengan 100 butir benih padi gogo varietas Inpago 8 pada setiap nampan. Setelah 7 hari penaburan benih dipndahkan ke dalam 25 gelas plastik yang telah dilapisi dengan tisue dan dibasahi dengan aquades. Masing-masing gelas plastik berisi 2 kecambah dengan dilebel notasi perlakuan dan ulangan. Setiap gelas plastik yang berisi kecambah diberi ekstrak air rumput teki sebanyak $10 \mathrm{ml}$. Pengamatan parameter perkecambahan dilakukan setelah 12 hari penanaman.

Pengamatan panjang tunas diukur dari pangkal sampai ujung daun dengan menggunakan penggaris dan dinyatakan dalam satuan sentimeter. Menghitung berat segar kecambah dengan menimbang akar dan tunas menggunakan timbangan digital dalam satuan miligram. Kecambah padi yang telah diukur berat segarnya dikeringkan menggunakan oven selama 2 jam dengan suhu $130^{\circ} \mathrm{C}$, selanjutnya ditimbang kembali menggunakan timbangan digital sebagai berat kering dinyatakan dalam miligram. Kandungan air relatif kecambah padi dihitung dengan rumus (Yamasaki \& Dillenburg, 1999) :

$$
\text { Kadar Air Relatif }=\frac{M 1-M 2}{M 1} \times 100 \%
$$

Keterangan : $\quad$ M1 = Berat segar kecambah $\quad$ M2 = Berat kering kecambah 
Kandungan klorofil ditentukan menurut (Miazek, 2002), 1 gram daun tanaman padi digerus sampai halus didalam mortar, kemudian ditambahkan $5 \mathrm{ml}$ etanol $96 \%$. Ekstrak disaring kedalam tabung reaksi. Ekstrak klorofil diukur absorbansinya pada panjang gelombang 649 dan $665 \mathrm{~nm}$. Kadungan klorofil dinyatakan dalam miligram/gram jaringan dan dihitung dalam persamaan berikut :

$$
\begin{aligned}
& \text { Chla }=13.36 \mathrm{~A}_{665}-5.19 \mathrm{~A}_{649}\left(\frac{\mathrm{v}}{\mathrm{w} \times 1000}\right) \\
& \text { Chlb }=27.43 \mathrm{~A}_{649}-8.12 \mathrm{~A}_{665}\left(\frac{\mathrm{v}}{\mathrm{w} \times 1000}\right) \\
& \text { Chltotal }=22.24 \mathrm{~A}_{649}-5.24 \mathrm{~A}_{665}\left(\frac{\mathrm{v}}{\mathrm{w} \times 1000}\right)
\end{aligned}
$$

Keterangan :

Chla $=$ klorofil a

Chlb $=$ klorofil $b$

Chltotal $=$ klorofil total

$\mathrm{A}_{665}=$ absorbansi pada panjang gelombang $665 \mathrm{~nm}$

$\mathrm{A}_{649}=$ absorbansi pada panajng gelombang $649 \mathrm{~nm}$

$\mathrm{V}=$ volume etanol

$\mathrm{W}=$ Berat daun

Homogenesis ragam ditentukan dengan uji Levene pada taraf nyata 5\%. Analisis ragam dan uji Beda Nyata Jujur (BNJ) dilakukan pada taraf nyata 5\%. Hubungan antara konsentrasi ekstrak air rumput teki dengan variabel pertumbuhan ditentukan berdasarkan regresi linear, dengan keeratan hubungan didasarkan kepada nilai koefisien korelasi atau r.

\section{HASIL DAN PEMBAHASAN}

Panjang Tunas. Rata-rata panjang tunas kecambah padi gogo varietas Inpago 8 setelah perlakuan ekstrak air rumput teki ditunjukkan pada Tabel 1. Analisis ragam pada taraf nyata 5\% menunjukkan bahwa ekstrak air rumput teki berpengaruh nyata terhadap panjang tunas kecambah benih padi gogo varietas Inpago 8.

Tabel 1. Rata-rata panjang tunas kecambah padi gogo varietas Inpago 8

\begin{tabular}{cc}
\hline $\begin{array}{c}\text { Konsentrasi } \\
(\% \text { v/v) }\end{array}$ & $\begin{array}{c}\text { Panjang tunas }(\mathbf{c m}) \\
\overline{\mathbf{Y}} \pm \mathbf{S E}\end{array}$ \\
\hline 0 (kontrol) & $2,86 \pm 0,10^{\mathrm{a}}$ \\
5 & $4,14 \pm 0,39^{\mathrm{ab}}$ \\
10 & $3,46 \pm 0,26^{\mathrm{ac}}$ \\
15 & $3,95 \pm 0,26^{\mathrm{a}}$ \\
20 & $3,08 \pm 0,38^{\mathrm{a}}$ \\
\hline
\end{tabular}

Keterangan : angka yang diikuti oleh huruf yang sama tidak berbeda nyata

Uji Tukey menunjukkan bahwa tidak ada perbedaan yang nyata dalam panjang tunas antara kontrol dan perlakuan. Namun, ada perbedaan yang nyata dalam panjang tunas kecambah antara perlakuan $5 \% \mathrm{v} / \mathrm{v}$ dan $10 \%$ v/v. Hubungan antara konsentrasi ekstrak air rumput teki dengan panjang tunas kecambah padi gogo varietas Inpago 8 ditunjukkan pada Gambar 1.

Hubungan antara konsentrasi ekstrak air rumput teki dengan panjang tunas padi gogo varietas Inpago 8 adalah kuadratik dengan koefisien determinasi $=0,59$ dan koefisien korelasi $=0,77$ yang menunjukkan hubungan yang kuat antara konsentrasi ekstrak air rumput teki dengan panjang tunas. Panjang tunas maksimum adalah $3,95 \mathrm{~cm}$ yang diperoleh pada konsentrasi ekstrak air rumput teki 10,3\% v/v.

Hasil penelitian ini tidak sesuai dengan hasil penelitian yang dilakukan oleh Ali, Ahmad, \& Mohsen (2014), bahwa ekstrak rumput teki menyebabkan penurunan panjang tunas pada konsentrasi 10, 20, 30, dan 
$40 \%$ secara signifikan dibandingkan dengan kontrol pada tanaman tomat. Efek dari senyawa yang dihasilkan oleh rumut teki seharusnya dapat terjadi diawal siklus hidup dari tanaman tertentu sehingga dapat menghambat perkecambahan benih dan pertumbuhan bibit. Penelitian lain juga melaporkan bahwa panjang tunas dipengaruhi oleh ekstrak air rumput teki dan menunjukkan perbedaan yang signifikan pada konsentrasi 50\% esktrak air rumput teki (Sardoei et al., 2013).

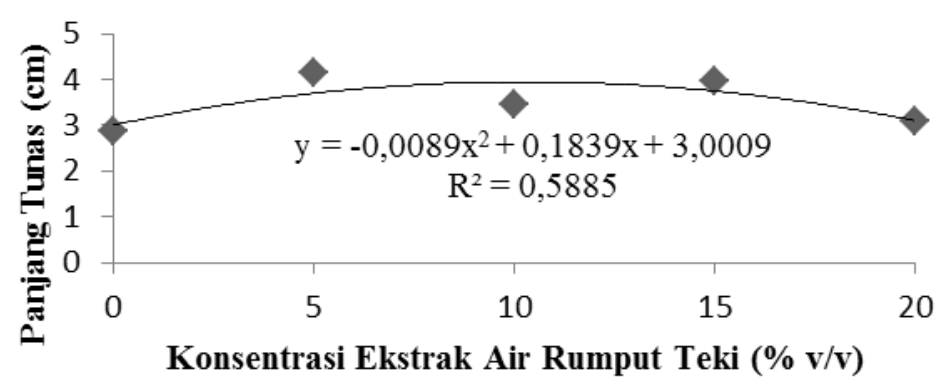

Gambar 1. Hubungan antara konsentrasi ekstrak air rumput teki dengan panjang tunas kecambah padi gogo varietas Inpago 8.

Berat Segar Kecambah. Rata-rata berat segar kecambah padi gogo varietas Inpago 8 setalah perlakuan ekstrak air rumput teki ditunjukkan pada Tabel 2. Analisis ragam pada taraf nyata 5\% menunjukkan bahwa perlakuan ekstrak air rumput teki berpengaruh nyata terhadap berat segar kecambah benih padi gogo varietas Inpago 8.

Tabel 2. Rata-rata berat segar kecambah padi gogo varietas Inpago 8

\begin{tabular}{cc}
\hline $\begin{array}{c}\text { Konsentrasi } \\
(\% \text { v/v })\end{array}$ & Berat Segar Kecambah $(\mathbf{m g})$ \\
\hline $0($ kontrol $)$ & $\overline{\mathbf{Y}} \pm \mathbf{S E}$ \\
5 & $52,58 \pm 5,21^{\mathrm{a}}$ \\
10 & $75,84 \pm 3,49^{\mathrm{b}}$ \\
15 & $65,90 \pm 5,39^{\mathrm{a}}$ \\
20 & $71,38 \pm 2,27^{\mathrm{a}}$ \\
\hline
\end{tabular}

Keterangan : angka yang diikuti oleh huruf yang sama tidak berbeda nyata

Uji Tukey menunjukkan bahwa ada perbedaan yang nyata dalam berat segar kecambah antara kontrol dan perlakuan $5 \%$. Namun, ada perbedaan yang nyata dalam berat segar kecambah antara perlakuan $10 \%$, $15 \%, 20 \%$, dengan perlakuan 5\%. Hubungan antara konsentrasi ekstrak air rumput teki dengan berat segar kecambah padi gogo varietas Inpago 8 ditunjukkan pada Gambar 2.

Hubungan antara konsentrasi ekstrak air rumput teki dengan berat segar kecambah padi gogo varietas Inpago 8 adalah kuadratik dengan koefisien determinasi $=0,55$ dan koefisien korelasi $=0,74$ yang menunjukkan hubungan yang kuat antara konentrasi ekstrak air rumput teki dengan berat segar kecambah. Berat segar kecambah maksimum adalah 73,21 mg yang diperoleh pada konsentrasi ekstrak air rumput teki $14,10 \% \mathrm{v} / \mathrm{v}$. 


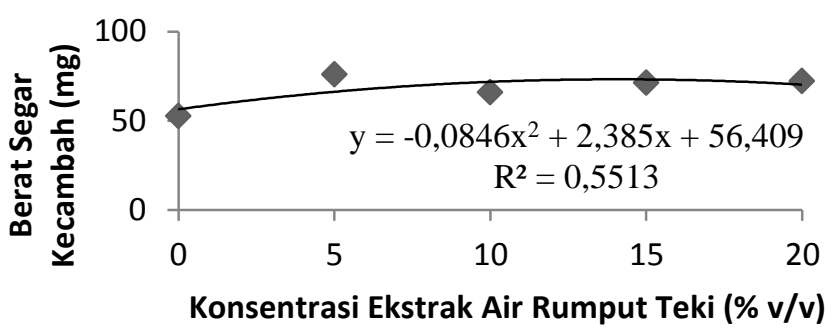

Gambar 2. Hubungan antara ekstrak air rumput teki dengan berat segar kecambah padi gogo varietas Inpago 8.

Hasil penelitian ini tidak sesuai dengan hasil penelitian sebelumnya oleh Darmanti, Santosa, Kumala, \& Hartanto (2015), yang menunjukkan bahwa ekstrak rumput teki dapat secara signifikan menurunkan nilai berat segar kecambah kedelai. Semakin tinggi konsentrasi maka semakin rendah nilai berat segar kecambah kedelai. Efek alelopati terutama disebabkan oleh senyawa fenolik El-Rokiek et al (2010), melaporkan bahwa esktrak air rumput teki mengandung asam ferulik, asam klorogenik, asam hidrobenzoit, dan asam kafeit. Gulma seperti rumput teki ini juga memberi efek alelopati pada perkecambahan dan pertumbuhan tanaman dengan melepaskan senyawa yang dapat masuk ke dalam tanah (Tanveer et al., 2010).

Berat Kering Kecambah. Rata-rata berat kering kecambah padi gogo varietas Inpago 8 setalah perlakuan ekstrak air rumput teki ditunjukkan pada Tabel 3. Analisis ragam pada taraf nyata 5\% menunjukkan bahwa perlakuan ekstrak air rumput teki tidak berpengaruh nyata terhadap berat kering kecambah benih padi gogo varietas Inpago 8.

Tabel 3. Rata-rata berat kering kecambah padi gogo varietas Inpago 8

\begin{tabular}{cc}
\hline $\begin{array}{c}\text { Konsentrasi } \\
(\boldsymbol{\%} \text { v/v })\end{array}$ & Berat Kering Kecambah $(\mathbf{m g})$ \\
\hline 0 (kontrol) & $\overline{\mathbf{Y}} \pm \mathbf{S E}$ \\
5 & $14,98 \pm 1,26$ \\
10 & $17,08 \pm 0,75$ \\
15 & $17,04 \pm 0,96$ \\
20 & $17,88 \pm 1,27$ \\
\hline
\end{tabular}

Hasil berat kering yang didapat dari penelitian ini berbeda dengan hasil penelitian sebelumnya. Penelitian sebelumnya yang dilakukan oleh Mandal et al. (2005), menunjukkan bahwa pemberian ektrak rumput teki dapat secara signifikan mengurangi berat kering dari bibit mentimun. Hasil yang sama diperoleh oleh Alsaadawi \& Salih (2009), yang menunjukkan penurunan pertumbuhan akar dan tunas pada tanaman tomat dan mentimun. Penurunan berat kering dapat terjadi dikarenakan ketidakseimbangan dalam menyerap air saat proses perkecambahan dan pertumbuhan akibat terhambat oleh alelopati dari ekstrak rumput teki (Blum et al., 1999). Penelitian oleh Siregar et al. (2017), melaporkan terjadi penurunan berat kering pada tumbuhan bayam berduri setelah pemberian ekstrak umbi teki. Semakin rendah berat kering maka semakin tinggi alelopati umbi teki yang diberikan sehingga dapat terjadi penghambatan pada saat melakukkan fotosintesis. Hal ini dapat menyebabkan enzim yang dibutuhkan dapat terhambat sehingga terjadi penurunan berat kering pada bayam berduri. Pendapat ini juga dinyatakan oleh Yulifrianti et al. (2015), bahwa diduga ekstrak serasah daun mangga dapat menghambat proses fotosintesis melalui penghambatan enzim-enzim yang diperlukan dalam proses fotosintesis sehingga dapat menurunan berat kering tanaman.

Kandungan Air Relatif. Rata-rata kandungan air relatif kecambah padi gogo varietas Inpago 8 setalah perlakuan ekstrak air rumput teki ditunjukkan pada Tabel 4. Analisis ragam pada taraf nyata 5\% 
menunjukkan bahwa perlakuan ekstrak air rumput teki berpengaruh nyata terhadap kandungan air relatif kecambah benih padi gogo varietas Inpago 8 .

Tabel 4. Rata-rata kadar air relatif kecambah padi gogo varietas Inpago 8

\begin{tabular}{cc}
$\begin{array}{c}\text { Konsentrasi } \\
(\boldsymbol{\%} \mathbf{v} / \mathbf{v})\end{array}$ & Kadar Air Relatif $(\%)$ \\
$\overline{\mathbf{Y}} \pm \mathbf{S E}$ \\
\hline 0 (kontrol) & $69,66 \pm 1,43^{\mathrm{a}}$ \\
5 & $77,31 \pm 1,25^{\mathrm{b}}$ \\
10 & $73,87 \pm 1,06^{\mathrm{a}}$ \\
15 & $74,93 \pm 1,85^{\mathrm{a}}$ \\
20 & $72,13 \pm 2,38^{\mathrm{a}}$ \\
\hline
\end{tabular}

Keterangan : angka yang diikuti oleh huruf yang sama tidak berbeda nyata

Uji Tukey menunjukkan bahwa ada perbedaan yang nyata dalam kadar air relatif kecambah antara kontrol dan perlakuan 5\%. Namun, ada perbedaan yang nyata dalam kadar air relatif kecambah antara perlakuan $10 \%, 15 \%, 20 \%$, dengan perlakuan 5\%. Hubungan antara konsentrasi ekstrak air rumput teki dengan kadar air relatif kecambah padi gogo varietas Inpago 8 ditunjukan pada Gambar 4.

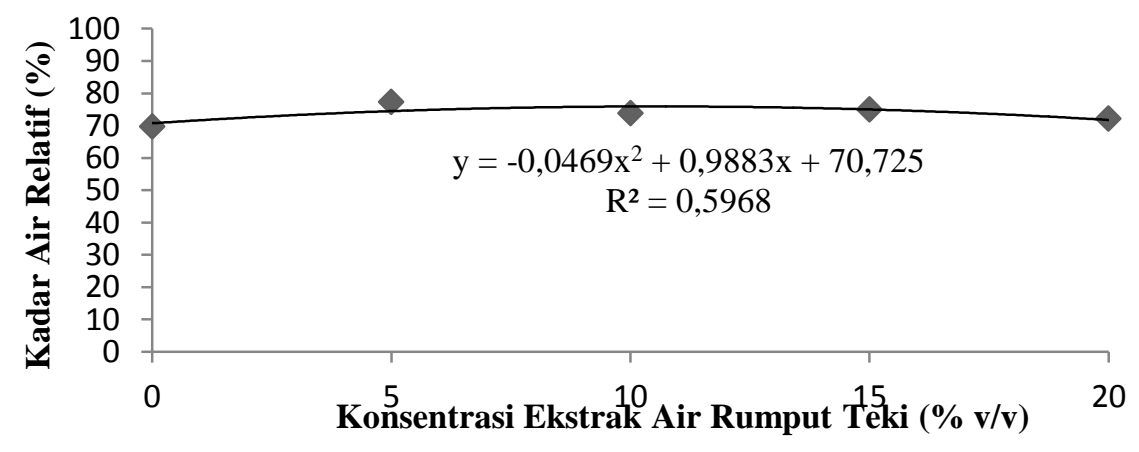

Gambar 4. Hubungan antara konsentrasi ekstrak air rumput teki dengan padi gogo varietas Inpago 8.

Hubungan antara konsentrasi ekstrak air rumput teki dengan kadar air relatif kecambah padi gogo varietas Inpago 8 adalah kuadratik dengan koefisien determinasi $=0,60$ dan koefisien korelasi $=0,77$ yang menunjukkan hubungan yang kuat antara konsentrasi ekstrak air rumput teki dengan kadar air relatif kecambah padi. Kadar air relatif kecambah maksimum adalah 75,93 mg yang diperoleh pada konsentrasi ekstrak air rumput teki 10,54\% v/v.

Kandungan Klorofil Total. Rata-rata klorofil total kecambah padi gogo varietas Inpago 8 setalah perlakuan ekstrak air rumput teki ditunjukkan pada Tabel 5. Analisis ragam pada taraf nyata 5\% menunjukkan bahwa perlakuan ekstrak air rumput teki berpengaruh nyata terhadap klorofil total kecambah benih padi gogo varietas Inpago 8.

Tabel 5. Rata-rata kandungan klorofil total kecambah padi gogo varietas Inpago 8

\begin{tabular}{cc}
$\begin{array}{c}\text { Konsentrasi } \\
(\% \mathbf{v} / \mathbf{v})\end{array}$ & $\begin{array}{c}\text { Klorofil Total }(\mathbf{m g} / \mathbf{g} \text { jaringan }) \\
\overline{\mathbf{Y}} \pm \mathbf{S E}\end{array}$ \\
\hline $0 \%$ (kontrol) & $1,50 \pm 0,16^{\mathrm{a}}$ \\
$5 \%$ & $1,03 \pm 0,10^{\mathrm{a}}$ \\
$10 \%$ & $0,28 \pm 0,28^{\mathrm{b}}$ \\
$15 \%$ & $0,65 \pm 0,32^{\mathrm{bc}}$ \\
$20 \%$ & $1,18 \pm 0,15^{\mathrm{ac}}$ \\
\hline
\end{tabular}

Keterangan : angka yang diikuti oleh huruf yang sama tidak berbeda nyata 
Uji Tukey menunjukkan bahwa ada perbedaan yang nyata dalam klorofil total kecambah antara kontrol dan perlakuan $10 \%$ dan $15 \%$. Namun, ada perbedaan yang nyata dalam klorofil total kecambah antara perlakuan 5\% dengan perlakuan 10\%, 15\%, dan 20\%. Hubungan antara konsentrasi ekstrak air rumput teki dengan klorofil total kecambah padi gogo varietas Inpago 8 ditunjukkan pada Gambar 5.

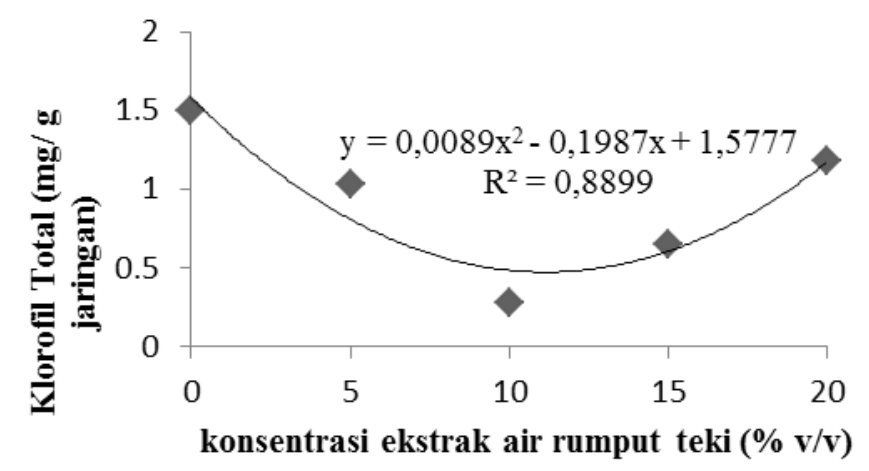

Gambar 5. Hubungan antara ekstrak air rumput teki dengan kandungan klorofil total padi gogo varietas Inpago 8.

Hubungan antara konsentrasi ekstrak air rumput teki dengan klorofil total kecambah padi gogo varietas Inpago 8 adalah kuadratik dengan koefisien determinasi = 0,89 dan koefisien korelasi = 0,94 yang menunjukkan hubungan yang kuat antara konsentrasi ekstrak air rumput teki dengan klorofil total kecambah padi. Klorofil total kecambah minimum adalah $0,47 \mathrm{mg} / \mathrm{g}$ jaringan terjadi pada konsentrasi ekstrak air rumput teki $11,16 \% \mathrm{v} / \mathrm{v}$.

Hasil penelitian ini pada kadar klorofil total sama dengan hasil penelitian (Nadu, 2014) yang menyatakan bahwa pada konsentrasi tinggi yaitu 25\% mengalami penurunan kadar klorofil bibit padi varietas ADT-36, BPT, dan IR-20 dibandingkan pada kontrol. Penurunan ini dimungkinkan karena adanya alelopati yang terkandung pada rumput teki sehingga menghambat pertumbuhan padi. Semakin tinggi konsentrasi ekstrak maka penurunan akan semakin terlihat pada pertumbuhan bibit padi. Penelitian oleh Jai et al. (2010), melaporkan bahwa Cassia occidentalis, Rumex dentatus, Calotropis procera dan Whithanias omnifera dapat menurunkan pertumbuhan dari tanaman Parthenium hysterophorus. Berdasarkan penelitian yang dilakukan Ismail \& Mohammed (2011), menunjukkan efek penghambatan Cyperus iria pada kandungan klorofil daun padi. Penurunan ini terjadi karena adanya alelopati yang terkandung dalam gulma tersebut. Kandungan klorofil juga dapat berpengaruh terhadap berat kering dari suatu tanaman tertentu. Penurunan kandungan klorofil pada daun menyebabkan penghambatan dalam fotosintesis dan pertumbuhan tanaman.

\section{KESIMPULAN DAN SARAN}

Berdasarkan hasil penelitian diperoleh kesimpulan bahwa ekstrak air rumput teki pada konsentrasi dibawah $14 \%$ bersifat stimulator pertumbuhan, namun inhibitor biosintesis klorofil total.

Perlu dilakukan uji lanjut dengan menggunakan padi gogo varietas lainnya pada konsentrasi yang lebih tinggi.

\section{DAFTAR PUSTAKA}

Aak 1995. Berbudidaya Tanaman Padi. Kanisius. Yogyakarta: Kanisius.

Ali, D., Ahmad, A. \& Mohsen, N. 2014. Determination of Allelopathic Effect of Purple Nutsedge (Cyperus rotundus) on Germination and Initial Development of Tomato (Lycopersicum esculentum). Indian Journal of Fundamental and Applied Life Sciences, 4(2): 576-580. 
Alsaadawi, I.S. \& Salih, N.M.M. 2009. Allelopathic Potential of Cyperus rotundus L. Interference with Crops. Allelopathy Journal, 23(1).

Blum, U., Shafer, S.R. \& Lehman, M.E. 1999. Evidence of Inhibitory Allelopathic Interactions Involving Phenolic Acids in Field Soils: Concepts vs. An Experimental Model. Critical Reviews in Plant Sciences 18, 93-673.

Darmanti, S., Santosa, Kumala, D. \& Hartanto, L.. 2015. Allelopathic Effect of Cyperus rotundus L. on Seed Germination and Initial Growth of Glycine max L. ev. Grobogan. BIOMA Journal., 17(2): 61-67.

El-Rokiek, K.G., El-Masry, R.R.N.L., Messiha \& Ahmed, S.A. 2010. Messiha and S.A. Ahmed. 2010. The Allelopathic Effect Of Mango Leaves On The Growth and Propagative Capacity Of Purple Nutsedge (Cyperus rotundus L.). Am. Joural Science, 6(9): 151-159.

Ismail, B.S. \& Mohammed, A.B.. 2011. The Inhibitory Effect of Grasshopper's Cyperus (Cyperus iria L.) on the Seedling Growth of Five Malaysian Rice Varieties. Journal Tropical Life Sciences Research, 22(1): 81-89.

Jai, K., Disha, J. \& Paul, M.S. 2010. Allelopathic Effect of Selected Weeds on Biochemical Activity of Parthenium hysterophorus. Current Research Journal Of Biologi Science, 2(24): 238-240.

Mandal, M.P., Das, D.K. \& Singh, A.K. 2005. Impact of Leaf Extract of Populus Deltoids Marsh on Germination and Seedling Growth of Green Gram (Vigna radiata L.). Allelopathy Journal, 16(2): $317-322$.

Miazek, K. 2002. Chlorophyll Extraction From Harvested Plant Material. Supervisor. Prof. Dr. Ha. Inz. Stainslaw Lekadowicz.

Nadu, T. 2014. Allelopathic Potential of Cyperus rotundus L. and Cynodan dactylon L. on Germination and Growth Responses of Some Rice Cultivars. International Journal of Current Biotechnology, 2(12): $41-45$.

Pertanian, .Badan Penelitian dan Pengembangan 2010. Road Map Strategi Sektor Pertanian Menghadapi Perubahan Iklim. Kementerian Pertanian.

Sardoei, A.S., Mustafa, N., Morteza, S.F. \& Mostafa, S. 2013. The Allopathic Effects of Cyperus rotundus on the Germination of Lycopersicon esculentum L. var Chef Flat. International Journal of Advanced Biological and Biomedical Research, 12(1): 1551-1557.

Siregar, E.N., Agung, N. \& Roedy, S. 2017. Uji Alelopati Ekstrak Umbi teki pada Gulma Bayam Duri (Amaranthus Spinosus L.) dan Pertumbuhan Tanaman jagung Manis (Zea mays L. saccharata). Jurnal Produksi Tanaman, 5(2): 290-298.

Tanveer, A., Rehman, A., Javaid, M., Abbas, R.., Sibtain, M., Ahmad, A.U., Ibin-I-Zamir, M.S., Chaudhary, K.M. \& Aziz, A. 2010. Allelopathic Potential of Euphorbia helioscopia L. Against Wheat (Triticum aestivum L.), Chicpea (Cicer arietinum L.) and Lentil ( Lens cularis Medic). Turki Jurnal Agric, 34: $75-81$.

Yamasaki, S. \& Dillenburg, L.. 1999. Measurement Of Leaf Relative Water Content In Angusitifolia Revista Brarileira de Fisiologis Fegetal. 11(2): 69-75.

Yulifrianti, E., Linda, R. \& I., L. 2015. Potensial Alelopati Ekstrak Seresah Daun Mangga (Mangifera indica L.) terhadap Pertumbuhan Gulma Rumput Grinting (Cynodon dactylon L.). Press. J. Protobiont, 4(1): 46-51. 